\title{
ERRATUM
}

\section{A decade of letrozole: FACE}

\section{Joyce O'Shaughnessy}

Published online: 22 February 2008

(C) Springer Science+Business Media, LLC. 2008

\section{Erratum to: Breast Cancer Res Treat (2008) 105(Suppl 1) DOI 10.1007/s10549-007-9702-9}

Due to an oversight, Financial Disclosure of the Authors in the above referenced supplement was not published as required. All authors have acknowledged and signed a statement of Financial Disclosure/Conflict of Interest and certify that no honoraria for the work therein were received.

The online version of the original article can be found under doi:10.1007/s10549-007-9702-9.

J. O'Shaughnessy $(\varangle)$

Texas Oncology, P.A, Baylor Sammons Cancer Center and US Oncology, 3535 Worth Street, Ste. 500, Dallas, TX 75246, USA

e-mail: Joyce.O'Shaughnessy@usoncology.com 